Morgan (British Leather Manufacturers' Research Association), who showed that, despite the obvious complexity of the wearing process of shoe soles, there is a good correlation between the results obtainod in abrasion tests and durability measured in wear trials of shoes. In favourable cases, the closeness of the correlation seems to be limited by the unavoidable errors associated with the wear trials (and amounting to a few per cent) rather than to any other cause.

R. G. Mitton

\title{
INTERNATIONAL UNION OF FOREST RESEARCH ORGANIZATIONS
}

$\mathrm{T}$

HE thirteenth Congress of the International Union of Forest Research Organizations was held in Vienna during September 11-16 under the presidency of Mr. James Macdonald, director of research and education in the Forestry Commission, London. Vienna was the birth-place of the Union, and the small body of specialists, members of Austrian, German and Swiss forest research institutes, who first met (at Mariabrunn) in 1893, would surely have been gratified at the ramifying growth and vigour of their brain-child. More than 400 delegates, an all-time record, attended the Congress from about three dozen countries, with particularly strong contingents from Finland, Germany, Japan, Scandinavia, the United States and the U.S.S.R.

All working sessions were held at the Wilhelm Exner Haus, Hochschule für Bodenkultur, and the opening and closing ceremonies at the more central Haus der Industrie. The Congress was formally opened by the Federal Minister of Agriculture and Forestry, who reviewed the great changes-territorial losses, damage, over-exploitation and neglect-wrought by two World Wars in the forest economy of Austria and emphasized the growing importance of the forests, both State and private, not only as suppliers of timber, internally and abroad, but also as stabilizers of mountain slopes and guarantors of the water supply. The Marshall Plan had given a great impetus to rehabilitation, and now an extensive programme of torrent- and avalanche-control, embracing both engineering works and reforestation, was under way, backed by a carefully conceived plan of research.

The main work of the Congress was, as usual, carried out in the sections, of which (inclusive of bibliography) there were ten, which constitute the living heart of the Union. The section leaders, who continue in office between Congresses, are responsible for keeping in touch with the research workers in their respective fields of action, for distributing information of interest to specialist working groups and other members of their section, for initiating action as necessary, and preparing for and conducting their sectional meetings at Congresses.

Section 11 (Forestry Influences), under Dr. H. Storey of Washington, dealt with three main topics: management of forested watersheds for water supply (where stress was laid on the need for now measurement techniques and instrumentation), the role of forests and engineering structures in the control of floods and erosion (emphasizing the supplementary functions of biological and engineering methods) and shelterbelts, and ended with appointing working groups to initiate and co-ordinato work in each of these fields. Section 21 (Site Factors), under Prof. de Philippis of Florence, had forest typology, the influence of forest stands on the soil, and biological factors of forest regeneration as its main topies, and set up a joint working group with Section 25 in order to study what are the best criteria for assessing the quality of sites and the relationships between environ- mental factors and the potential productivity of sites. In Section 22 (Forest Plants) under Dr. C. Syrach Larsen of Horsholm, the chief topics discussed were seed production problems in forest trees and the growing of pines in the tropies and subtropies; a working group was formed on provenance research. This Section has hitherto concentrated on tree breeding, but is becoming increasingly interested, in physiology. Dr. Leibundgut of Zurich presided over Section 23 (Silviculture), in which a great variety of subjects was discussed, notably: silvicultural problems raised by the general unsaleability of smalldimensional timber-a topic of world-wide interestfor which a new working group was set up; silvicultural problems of tropical forests; soil amelioration and weed control in nurseries; and root formation and competition. This Section is also busy, in collaboration with the Bibliographical Section, on terminology in its field. Section 24 (Forest Protection), under Prof. A. Biraghi of Florence, dealt mainly with insect population dynamics-especially the influence of manuring of forest stands on the development of populations of noxious insects, about which there is some controversy; mycorrhiza research; international co-operation in forest disease researeh and in quarantine measures; and problems of smoke and industrial fumes damage to forest growth. It also created a fifth working group to study the important question of fire control.

Section 25 (Growth and Yield), under Prof. S. Firat of Istanbul, discussed mainly: the use of climate site indices-concluding that these cannot by themselves afford an accurate guide to the quality class of individual forest sites and setting up a joint working group with Section 21 (see above); the use of electronic digital computers in forest research recommending inter alia the compilation of a register of existing computer programmes of interest to foresters and an index of organizations and individuals that are actively using computers; increment determination in uneven-aged tropical forests (a matter of great present-day interest) and increment detormination by borings-in both of which, it was agreed, investigations were not sufficiently advanced to permit anything but tentative conclusions. This Section has a permanent working group that advises the Union on all matters concerned with aerial photography, photo interpretation and photogrammetry, and maintains effective links with Commission 7 of the International Society of Photogrammetry; the report of this group was approved and its membership is being widened. The Section also recommended the formation by mathematical specialists of advisory groups for helping forest statisticians, both by suggesting improvements in current university curricula on statistical methods and by organizing the collection and distribution of case studies and other information of value for the statistical planning of forest research. Prof. J. Speer of Munich led Section 31 (Forest Economics), which formulated and recommended a special accounting system for forest com- 
mercial enterprises and a corpus of economic terms that could be used by all countries. It also discussed the difficult topic of the measurement of forest work productivity with Section 32 (Operational Efficiency) the other main topics of which, under the chairmanship of Prof. V. Sundberg of Stockholm, were the effects of noise and vibration on the forest worker and the establishment of university courses in operational efficiency. Section 41 (Mechanical Conversion), led by Prof. J. Campredon of Paris, discussed many aspects of this subject and decided to enlarge its field of study so as to embrace all forest products (this to be the new name of the Section), with three initial working groups for wood quality, behaviour of wood exposed to fire, and sawing and machining.

Finally, on the initiative of Austria and Germany, the Union decided to create a new section, Section 11, on the History of Forestry, with Prof. von Mantel (West Gormany) as leader.

The Bibliographical Section, which is actually a joint committee of the Food and Agriculture Organization and Union representatives, met as usual several days before the Congress, under the chairmanship of Prof. E. Saari of Helsinki. It was concerned mainly with the prosecution of two long-term projects-further accurate translations of the classification now widely accepted in the world of forestry science (The Oxford System of Decimal Classification for Forestry, of which English, French, German and Spanish authorized editions have already appeared) and speeding up the production on cards of a basic forest terminology in the English language, as an essential preliminary to the multilingual terminology project, sponsored jointly by the Food and Agriculture Organization and the Union.
Prof. J. Speer (West Germany) was elected to be president in succession to Mr. Macdonald, whose term of office expires at the end of the year. Dr. V. L. Harper (United States) was elected vice-president. Elections to the Permanent Committee (previous members in italics) were: Prof. N. Anutschin (U.S.S.R.), Prof. T. Bunusevac (Yugoslavia), Prof. J. Campredon (France), Dr. E. Holmsgaard (Denmark), Prof. A. Horky (Austria), Prof. M. Kreutzinger (Poland), Prof. A. de Phillipis (Italy), Dr. D. R. Redmond (Canada), Dr. H. Shirley (United States), and Dr. Saito (Japan), leaving two places to be filled by representatives from India and Latin America, not yet designated.

The International Council met on the concluding day, and agreed to the revised statutes which take into account recent decisions of and developments in the Union, the major changes boing to strengthen the position and powers of the enlarged Permanent Committee which is its executive body between Congresses. A new class of member-associate member--has also been created and the organizing of the secretariat, following its recent relinquishment by the Food and Agriculture Organization, has been entrusted to the president himself.

The Union accepted an invitation from Germany to hold the next Congress there. After the Congress at Vienna, about 130 of the delegates took part in strenuous study-tours that lasted for 11 days of magnificent weather and covered the whole country. One tour concentrated on silviculture and management, another on the many aspects of forest protection, and the third on mechanical developments in soil-cultivation and trenching, tree planting and tending, timber extraction and milling.

F. C. FORD-ROBERTSON

\section{NUTRITION AND POULTRY}

T HE Scottish Group of the Nutrition Society held its sixty-second meeting on September 30 in the College of Agriculture, University of Edinburgh. It took the form of a symposium entitled "Nutrition and Poultry". As the chairman, Prof. S. J. Watson (University of Edinburgh), pointed out in his opening remarks, since the subject was "Nutrition and Poultry" it was not confined to problems of poultry feeding but instead embraced broader aspects of nutrition in which work with poultry has contributed to knowledge.

Dr. W. P. Blount (British Oil and Cako Mills, Ltd., London) opened the proceedings with a very thorough exposition of the use of birds as experimental animals. Ho said that apart from some cage birds which have special uses, poultry were the most commonly choson birds for laboratory work, and he emphasized the advantages of their cheapness, availability and ease of management. Illustrating his talk with a series of informative slides, ho de. scribed different forms of housing, from brooders for small groups of chicks to intensive houses for many thousands of adult birds. He discussed optimal conditions of light, temperature and humidity, systems of feeding and ingredients of poultry diets. He concluded with a survey of the common diseases of poultry, and indicated that many of them could be controlled by good management and the judicious use of drugs such as antibiotics and coccidiostats.

In the following paper Dr. M. E. Coates (National Institute for Research in Dairying, Shinfield) dealt with problems of fundamental nutrition for which poultry have proved peculiarly suitable subjects, particularly in vitamin research. The examples quoted ranged from Eijkman's classic observation of polyneuritis in hens fed on polished rice, which led to the discovery of vitamin $\mathrm{B}_{1}$, to modern work on the isolation and function of vitamin $B_{12}$, a field in which work with poultry has played a major part. The developing chick embryo was cited as a very suitable organism for investigating the biochemical role of nutrients, as evidenced by experiments on the metabolism of vitamin $B_{12}$ and studies in tissue culture of the function of vitamin $A$. She described how chicks can be relatively easily maintained in a germ-free state and are thus becoming increasingly important in investigations of the relation of the alimentary microflora to nutrition.

Prof. S. Lepkovsky (University of California), who has used birds to study the nervous control of food intake, gave a fascinating dissertation on hunger, appetite and satiety. He described the influence of the central nervous system through hunger- and satioty-centres in the hypothalamus. He illustrated the psychological effects of these states amusingly and accurately in a series of lantern slides of "Hubert", an unfortunate character from a comic cartoon who was obliged to subsist on a low-calorie diet.

It has become common practice to include in diets for livestock non-nutritional additives that increase growth-rate and level of production. In reviewing additives for poultry diets Dr. J. H. Taylor, 